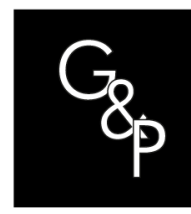

\title{
Main challenges in the identification and measurement of indirect costs in projects: a multiple case study
}

\author{
Principais desafios na identificação e mensuração dos custos \\ indiretos em projetos: um estudo de múltiplos casos
}

\author{
Bruno Cardoso Faria ${ }^{1}$, João Walter Saunders Pacheco do Vale ${ }^{2}$ (1), \\ Ana Lucia Figueiredo Facin ${ }^{2,3}$ (1), Marly Monteiro de Carvalho² (1) \\ ${ }^{1}$ BR+10 Ambiental Comércio e Serviços Ltda, São Paulo, SP, Brasil. E-mail: brunoc_faria@hotmail.com \\ ${ }^{2}$ Universidade de São Paulo - USP, Escola Politécnica - POLI, Departamento de Engenharia de Produção, São \\ Paulo, SP, Brasil. E-mail: walterrk@gmail.com; affacin@gmail.com; marlymc@usp.br \\ ${ }^{3}$ Universidade Estadual Paulista - UNESP, Itapeva, SP, Brasil. E-mail: affacin@gmail.com
}

How to cite: Faria, B. C., Vale, J. W. S. P., Facin, A. L. F., \& Carvalho, M. M. (2020). Main challenges

in the identification and measurement of indirect costs in projects: a multiple case study. Gestão \&

Produção, 27(1), e4913. http://doi.org/10.1590/0104-530X4913

\begin{abstract}
Projects have direct and indirect costs; the direct ones are easily identified and quantified, the indirect ones are difficult to control, because they are generated in favor of more than one project, and even if they are not directly related to the activities, they influence their budget. This study aims to present indirect cost identification methods, analyze the estimation models adopted for its measurement, and also analyze ways of appropriating costs in several projects. The method adopted was the analysis of multiple cases in companies of the industrial, commercial and services sectors. It was verified that projects with greater detail of the scope show less difficulty in identifying indirect costs, directly influencing the method of estimation adopted. The estimate for indirect costs is specific to each company, and its complexity is defined by the volume of data available. The appropriation of indirect costs differs between cases, but has similar objectives in its incorporation in the direct hours of the projects. It is worth highlighting the importance of project planning in the identification of indirect costs, in the choice of measurement methods, and also in the forms of costing for the budget.
\end{abstract}

Keywords: Project management; Cost management; Indirect costs; Project costing; Cost Appropriation.

Resumo: Projetos apresentam custos diretos e indiretos, os diretos são facilmente identificados e quantificados, já os indiretos, são difíceis de controlar, por serem gerados em prol de mais de um projeto, e mesmo não estando diretamente ligados às atividades, influenciam no seu orçamento. Este estudo visa apresentar métodos de identificação de custos indiretos, analisar modelos de estimativa adotados para sua mensuração, e também analisar formas de apropriação de custos em diversos projetos. O método adotado foi a análise de múltiplos casos, em empresas dos ramos industrial, comercial e serviços. Foi constatado que projetos com maior detalhamento do escopo mostram menor dificuldade na identificação de custos indiretos, influenciando diretamente o método de estimativa adotado. A estimativa de custos indiretos é específica para cada empresa, e sua complexidade é definida pela quantidade de dados

Received June 11, 2018 - Accepted Oct. 17, 2018

Financial support: None.

This is an Open Access article distributed under the terms of the Creative Commons Attribution License, which permits unrestricted use, distribution, and reproduction in any medium, provided the original work is properly cited. 
disponíveis. A apropriação de custos indiretos difere entre os casos, mas tem objetivos similares em sua incorporação nas horas diretas dos projetos. Destaca-se a importância do planejamento do projeto na identificação de custos indiretos, na escolha de métodos de mensuração, e também nas formas de custeio para o orçamento.

Palavras-chave: Gerenciamento de projetos; Gestão de custos; Custos indiretos; Custeio em projetos; Apropriação de custos.

\section{Introduction}

The constant changes in the world economy, driven by technological advances and ongoing encouragement of research and development of new products and services, forces companies to adapt strategies to meet new market demands. The survival of companies in this competitive market depends on great agility and efficiency in the decisions of their managers (Carvalho \& Rabechini, 2011). In this sense, Rodrigues et al. (2006) emphasize project management as a critical factor to address these issues, since well-managed, projects can potentiate the successful generation of new products, services and processes.

In this context, a critical step in the execution of projects, according to Gusberti et al. (2009), is the cost planning stage, considered one of the most complex and essential steps for a project to succeed, since it must guarantee that all the resources necessary to carry out the work are within the budget; moreover, that the project results expected by stakeholders are being accomplished. Kreisch (2013) adds that, in order to prepare a viable budget for a project, it is necessary to have a thorough knowledge of the direct and indirect costs for each activity, considering the quantities required, the time of use, the resulting financial costs and respective tax burdens.

A search in the Web of Science database of Clarivate Analytics, using the expressions "cost management" and "project management" together, presents 95 papers, of which 33 were published between 2016 and 2018, which shows that there is still interest of the researchers in this subject. If added to these expressions the word "indirect", only two studies (published in 2017 and 2016) mention indirect costs, which seems to show room for more research on this specific issue of the management of indirect costs in projects.

In addition, according to Zahaikevitch et al. (2013), the estimation of the direct costs of the project is not the most difficult task, because these costs are generated directly in the production of a good or service, which facilitates its identification. As they are directly related to the execution of the project, they do not need apportionment with other projects of the organization's portfolio. Indirect costs, that is, those that are not directly related to project execution, are more complex and difficult to estimate, especially in the planning and determining the project budget, when a more detailed definition and concrete knowledge are needed of the final product or service (Werolin, 1965; Gusberti et al., 2009; Zahaikevitch et al., 2013).

Also according to Berssaneti \& Carvalho (2015), maturity in project management significantly affects the success dimensions in projects, especially the time, cost and technical performance. Berssaneti \& Carvalho (2015) adds that an organization's maturity level is based on the use of specific project management practices. Obi et al. (2017), for example, discuss how the use of a cost management system can consolidate cost management practices in projects.

Therefore, it is essential to carry out research that contributes to theory and practice, in order to help project managers develop and consolidate practices that can lead to 
the development of budgets with well-defined methodologies and with the appropriate sizing of the project costing. The intention is to help improve the accuracy of costing planning in projects, and thus facilitate the achievement of the financial results expected by those involved in the project.

In this sense, this work aims mainly to discuss methods of identifying indirect costs in projects, analyzing the estimation models adopted by companies to measure these costs, as well as analyzing the ways of appropriating indirect costs in projects in companies in different branches of activity.

The methodological approach used was the study of multiple cases, carried out in companies with projects in the commercial, industrial and service provision areas. After conducting the study, a comparative analysis was performed between the results in order to provide subsidies to project managers to improve methods of estimating indirect costs in projects.

This study is structured in five sections. Section 2 presents a survey of theory on the subject. Section 3 describes how the case study was performed. Section 4 presents and discusses the results of the case study. Finally, section 5 presents the conclusions and recommendations of the research.

\section{Literature review}

This section presents the literature that deals with aspects related to the types of costs in projects and the importance of their management, highlighting the methods of costing, cost estimation and budgeting for projects. The discussion contemplates both the direct and indirect costs involved in the projects, focusing mainly on indirect costs.

\subsection{Types of costs in projects}

According to Carvalho \& Rabechini (2011), project costs are composed of direct and indirect costs. The direct ones are those that vary according to their use in the project, such as labor, materials and direct expenses with the project. The indirect ones do not vary according to their use, and are apportioned based on the system of accounts of the Work Breakdown Structure (WBS), such as indirect materials, indirect labor (i.e., human resources of quality audit, overhead of the support teams to the project). Usually, these costs are calculated according to a previously established periodicity.

Other costs that must be considered as an indirect cost of the project are the management and contingency reserves, and these reserves are used to meet the costs necessary to respond to possible known risks (identified and planned) and unknown risks that may occur during development of the project (Barbosa et al., 2014).

It is a consensus that direct costs are more easily identified and quantified because of their direct relationship with the resources needed to carry out project activities. Indirect costs are more difficult to control because they are the general costs of the organization incurred for the benefit of more than one project; however, even if they are not costs directly related to their activities, they can be aggregated in the total project budget (Carvalho \& Rabechini, 2011; Barbosa et al., 2014). 


\subsection{Cost management in projects}

As discussed by several authors, cost can be considered one of the limiting factors for the success of a project (Knutson \& Bitz, 1991; Lewis, 1995; Vargas, 2005; Costa et al., 2009; Kerzner, 2011). For this reason, cost planning is fundamental for companies having greater control over their actions, facilitating present and future decision making (Pinto et al., 2008).

Cost management involves several areas of knowledge in projects, especially those that are part of the triangle of the primary objectives, namely: scope, time and cost (Carvalho \& Rabechini, 2011). These objectives are closely interrelated and their control is important for obtaining the results of a project (Meredith \& Mantel, 2012). Oliveira (2003) points out that cost management is a great challenge in project management, since even if there are other parameters that influence the success of a project, costs are usually the first to be evaluated and those that cause the greatest impact on the result of the project.

On the other hand, the areas that make up the triple constraint of a project objectives are fundamental to success in cost management, since there is a strong integration between these areas, because any type of change in scope, time or cost, will directly influence the other areas of the triangle (Carvalho \& Rabechini, 2011). Therefore, cost management should ensure that all the resources considered to achieve the delimited scope, within the stipulated time frame for the project, are within the expected cost, in addition to meeting the requirements demanded by stakeholders (PMI, 2017).

According to Barbosa et al. (2014, p. 4), "[...] the cost of a project is based on the planning of all future activities, logically sequenced, according to the defined life cycle, and that consume resources of various types over time." Therefore, the life cycle of the project directly influences the measurement of its costs, since the cycle is composed of several phases of project development, limited by time. The cycle is established by "start, development and completion", with tangible deliveries at the conclusion of each phase (Vargas, 2005; Carvalho \& Rabechini, 2011; Barbosa et al., 2014; PMI, 2017).

Cost measurement should be carried out in the initial phases of the project, when the scope determinations and time schedules for each stage of the project are finalized, allowing the allocation of human resources and materials to be consumed to complete each phase and also the satisfaction of stakeholders (Lipovetsky et al., 1997; Atkinson, 1999; Tukel \& Rom, 2001; Shenhar et al., 2002; Santos \& Martins, 2008; Lacerda, 2009; Carvalho \& Rabechini, 2011). It is thus during the planning process that all the costs are calculated and organized to make clear the expected outflows and disbursements (Carvalho \& Rabechini, 2011).

\subsection{Costing methods for organizations}

Abbas et al. (2012) observe that the literature presents several costing methods (Table 1), applicable to different types of organizations. Some examples of the surveyed methods are absorption costing, variable costing, homogeneous sections costing (RKW), unit of production effort (UEP), and activity-based costing (ABC). 
Table 1. Costing methods.

\begin{tabular}{|c|c|c|}
\hline Costing Methods & Special Features & References \\
\hline $\begin{array}{l}\text { Absorption } \\
\text { Costing }\end{array}$ & $\begin{array}{l}\text { All the costs (direct, indirect, fixed and variable) } \\
\text { related to production efforts are apportioned to } \\
\text { all goods and services. Indirect costs can be } \\
\text { prorated in two ways: distributed proportionally } \\
\text { in the total cost of the manufactured products } \\
\text { or through distribution into production } \\
\text { departments and production support } \\
\text { departments. }\end{array}$ & $\begin{array}{c}\text { Martins (2003), } \\
\text { Schier (2006), } \\
\text { Abbas et al. (2012), } \\
\text { Zahaikevitch et al. } \\
\text { (2013) }\end{array}$ \\
\hline Variable Costing & $\begin{array}{l}\text { Only the direct and indirect costs involved in } \\
\text { the production of a given product are } \\
\text { considered, neglecting the fixed costs of the } \\
\text { organization. This method considers that fixed } \\
\text { costs exist independently of production and do } \\
\text { not influence the quantity of product produced. }\end{array}$ & $\begin{array}{c}\text { Martins (2003), } \\
\text { Schier (2006), } \\
\text { Abbas et al. (2012), } \\
\text { Zahaikevitch et al. } \\
\text { (2013) }\end{array}$ \\
\hline $\begin{array}{l}\text { Homogeneous } \\
\text { Sections Costing }\end{array}$ & $\begin{array}{l}\text { It consists of the division of costs into cost } \\
\text { centers, in which not only the production costs } \\
\text { but also all the expenses of the company are } \\
\text { apportioned in all the products developed. } \\
\text { The apportionment techniques are similar to } \\
\text { those of other methods, making the } \\
\text { appropriations of the direct and indirect costs of } \\
\text { production, based on the allocation of the } \\
\text { expenses of the various departments of the } \\
\text { company. }\end{array}$ & $\begin{array}{c}\text { Martins (2003), } \\
\text { Schier (2006), } \\
\text { Abbas et al. (2012) }\end{array}$ \\
\hline $\begin{array}{c}\text { Unit of Production } \\
\text { Effort }\end{array}$ & $\begin{array}{l}\text { Uses a unit of measure of the efforts and } \\
\text { resources applied to manufacturing one or } \\
\text { several products. The unit of measurement } \\
\text { should apply to all product types. The unit } \\
\text { measure is obtained by dividing the shop floor } \\
\text { into operative stations, which are responsible } \\
\text { for generating work and transforming the raw } \\
\text { material into finished products. Operational } \\
\text { stations include direct and indirect labor, } \\
\text { energy used in machinery, raw material, } \\
\text { maintenance and quality control, intellectual } \\
\text { planning work, among others intrinsically } \\
\text { related to the production process. }\end{array}$ & $\begin{array}{c}\text { Martins (2003), } \\
\text { Bornia (1995) }\end{array}$ \\
\hline $\begin{array}{l}\text { Activity Based } \\
\text { Costing }\end{array}$ & $\begin{array}{l}\text { Activity-based costing aims to minimize the } \\
\text { distortions caused by the apportionment of } \\
\text { indirect costs of the traditional methods } \\
\text { presented above. This method assumes that } \\
\text { resources are consumed by activities that } \\
\text { result in product development. Once the } \\
\text { activities are defined, the costs are allocated } \\
\text { through cost drivers, which represent the } \\
\text { amount of resource that will be required to } \\
\text { carry out the activity. }\end{array}$ & $\begin{array}{c}\text { Martins (2003), } \\
\text { Abbas et al. (2012) }\end{array}$ \\
\hline
\end{tabular}

Source: The authors (2018).

\subsection{Methods of estimating cost in projects}

The processes used to estimate the project costs, as well as the criteria, the methods and the techniques, vary in the different application areas, and are likewise related to the size and complexity of the project (Barbosa et al., 2014). 
Project estimates are commonly performed in two ways: detailed estimates or "at first glance". The former is developed considering the type of operation and the operating time, the human and material resources, among others things, and are employed in the various phases of the project life cycle. The latter is based on historical project data or on the estimator's experience (Gusberti et al., 2009). Carvalho \& Rabechini (2011) complement that working with analogies leads to inaccuracies even if there are historical data of similar projects.

Barbosa et al. (2014) say that the process of obtaining estimates is usually carried out based on experiences acquired in previous projects; however, companies more mature in cost management have specific methodologies to obtain the costs in the projects.

Rad (2002) argues that the availability of historical project data is critical for developing estimation models as well as for the overall process of cost estimating, because the historical data provide parameters for a more reliable estimation in the early stages of the project. In addition, Rad (2002) complements that when the elements of the Work Breakdown Structure (WBS) are broken down into work packages and their durations are determined, more accurate and reliable estimation methods could be developed. Gusberti et al. (2009) detail that the methods for estimating the durations and costs of the activities involve the unfolding of the project stages into work packages, making it possible to estimate the quantity of resources and time devoted to the project.

Several methods can be used to make preliminary project estimates, such as: Analogy, Parametric, Modular, Expert judgment, Organizational Knowledge, Proportion, and Interval Estimation. Note that the methods depend on the organization's policy, the project manager's experience and especially on the amount of information available at the time of estimation (Rad, 2002; Barbosa et al., 2014). Particular features of some methods are shown in Table 2.

Table 2. Methods of Estimating Cost in Projects.

\begin{tabular}{|c|c|c|}
\hline Methods & Particular Features of Estimating Cost Methods & References \\
\hline Bottom-up & $\begin{array}{l}\text { It establishes criteria for estimating the duration } \\
\text { and costs at the lower levels of the WBS, to obtain } \\
\text { a list of resources needed for the project, allowing } \\
\text { the sum of all smaller packages to establish the } \\
\text { cost and duration of the project. This estimation } \\
\text { model is usually considered the most labor-intensive, } \\
\text { but also the most accurate. }\end{array}$ & $\begin{array}{c}\text { PMI (2017), } \\
\text { Santos (2015) }\end{array}$ \\
\hline $\begin{array}{c}\text { Top-down or } \\
\text { Analogy }\end{array}$ & $\begin{array}{l}\text { The total cost of the project is considered for later } \\
\text { detailing the activities and feasibility of executing } \\
\text { the project; } \\
\text { An analogous activity is the basis for duration } \\
\text { estimation and costs estimation of one future } \\
\text { activity; } \\
\text { The purpose is to apply the estimation to situations } \\
\text { of scarce information, allowing making } \\
\text { assumptions about some environmental and } \\
\text { functional characteristics of the project, even if its } \\
\text { result is still imprecise; } \\
\text { This model is more reliable when it uses previous } \\
\text { projects that are really similar as a base, and } \\
\text { require preparation and technical ability from the } \\
\text { person responsible for the estimation. }\end{array}$ & $\begin{array}{c}\text { Santos (2015), } \\
\text { Rad (2002), PMI } \\
(2017), \\
\text { Rad (2002), } \\
\text { PMI (2017) }\end{array}$ \\
\hline
\end{tabular}


Table 2. Continued...

\begin{tabular}{|c|c|c|}
\hline Methods & Particular Features of Estimating Cost Methods & References \\
\hline $\begin{array}{c}\text { Parametric and } \\
\text { Modular }\end{array}$ & $\begin{array}{l}\text { They are performed using the project } \\
\text { characteristics in mathematical models and } \\
\text { algorithms; } \\
\text { Consider statistical relationships between historical } \\
\text { data and variables (square meter, kilometer run, } \\
\text { speed, etc.) necessary to calculate cost estimates } \\
\text { for a work package; } \\
\text { The results from these estimates are highly } \\
\text { accurate and can be applied to an entire project or } \\
\text { to parts of the project; } \\
\text { These models are more appropriate in phases that } \\
\text { have greater maturity of project objectives, and at } \\
\text { more detailed levels of the WBS. }\end{array}$ & $\begin{array}{l}\text { Barcellos et al. } \\
\text { (2003), } \\
\text { PMI (2017), Santos } \\
\text { (2015), } \\
\text { Rad (2002), PMI } \\
\text { (2017), } \\
\text { Rad (2002), } \\
\text { Barcellos et al. } \\
\text { (2003), PMI (2017) }\end{array}$ \\
\hline Proportion & $\begin{array}{l}\text { It is one of the most basic forms of estimation in } \\
\text { civil construction, in industrial and process projects. } \\
\text { Its main premise is that there is a linear relationship } \\
\text { between cost and duration of the project, as well as } \\
\text { between one or more basic characteristics of the } \\
\text { project. The basic features in this process are } \\
\text { related to any physical or performance attribute. } \\
\text { The quotients or factors are refined from personal } \\
\text { experience, company archives or published } \\
\text { scientific data. }\end{array}$ & Rad (2002) \\
\hline $\begin{array}{c}\text { Expert } \\
\text { judgment }\end{array}$ & $\begin{array}{l}\text { Developed through consultations with specialists in } \\
\text { various areas of activity, related to the project } \\
\text { activities, in order to prepare the cost estimates of } \\
\text { these activities. }\end{array}$ & $\begin{array}{l}\text { Rad (2002), } \\
\text { Barcellos et al. } \\
\text { (2003), Carvalho \& } \\
\text { Rabechini (2011) }\end{array}$ \\
\hline $\begin{array}{l}\text { Interval } \\
\text { Estimation }\end{array}$ & $\begin{array}{l}\text { It results from obtaining three possible estimates of } \\
\text { duration of activities, most likely, optimistic and } \\
\text { pessimistic. The most probable estimative is based } \\
\text { on the most probable scenario in which the } \\
\text { allocated resources are available and the other } \\
\text { assumptions of the project are also observed. } \\
\text { The optimist is based on the use of more positive } \\
\text { duration estimates. The pessimist, conversely, } \\
\text { considers the duration estimates to be more } \\
\text { negative, and thus longer; } \\
\text { When a set of three estimates is obtained for all } \\
\text { the elements of the WBS, a random number } \\
\text { generation tool can be used, allowing evaluating } \\
\text { the distributions and obtaining the most probable } \\
\text { estimates based on the random selection of the } \\
\text { estimates of each element. }\end{array}$ & $\begin{array}{c}\text { Rad (2002), PMI } \\
(2017), \text { Santos } \\
(2015) \\
\text { Carvalho \& } \\
\text { Rabechini (2011) }\end{array}$ \\
\hline
\end{tabular}

Source: The authors (2018).

\subsection{Budget in projects}

The budgeting methods use the projection of the estimated monetary resources so that they can be grouped to make up the total cost of the project and its appropriation over the schedule. In other words, to follow up the budget, the costs allocated to carry out the activities or work packages along the schedule should be part of the total cost of the project (Barbosa et al., 2014).

The total cost of the project subdivided throughout its life cycle is used to develop the baseline of project costs. The cost baseline is an important reference for controlling costs, allowing the project cost control throughout its life cycle and also the analysis of 
the restrictions of planned costs for each stage, without harming quality, timing, scope and risk of other project activities (Santos, 2015).

The most common way to represent the baseline of project costs is the $S$ curve, which enables an analysis of the approved costs for each project phase. In the graph of Figure 1, the $S$ curve is represented by the VP curve, constructed from the planned values for the cumulative costs of the project, curve $C$ represents the respective costs during the project (Santos, 2015). Figure 1 also permits to observe, in the abscissa axis, the variable project time (in days, months or years), and in the axis of the ordinates, the cumulative cost variable of the project (in monetary units).

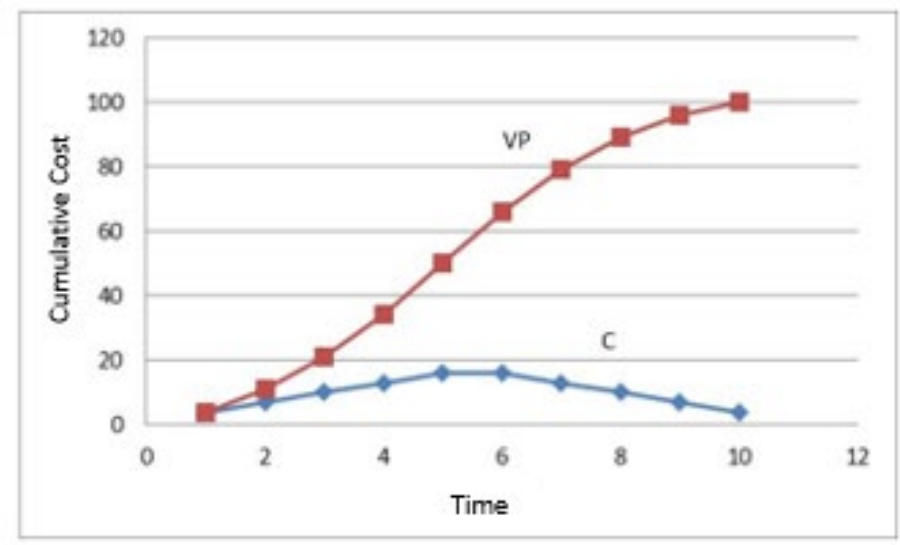

Figure 1. S-curve for project costs. Source: Adapted from Santos (2015).

According Figure 1, the costs represented in curve $C$ are lower in the initial phases of the project than in the intermediate phase, since during the intermediate phase, more resources are used for executing the activities, and the costs are reduced in the phase of project completion, when the activities are concluded.

From this representation, it is possible to calculate how much the project will spend, in monetary units, to carry out each work package (Barbosa et al., 2014). According to Oliveira (2003), preparing the budget baseline is one of the most important tasks, particularly in the early stages of the project, as this tool allows determining the distribution of costs over time for all project activities.

\section{Research methodology}

The main objectives of the research were: to discuss methods of identifying the indirect costs of the projects developed in different branches, in the companies studied; to analyze their methodologies to estimate the indirect costs; and also, to analyze the methods adopted for the appropriation of indirect costs in the company's projects.

Since the interest of the research focuses on these methods that are part of a larger project cost management process, Martins (2004) indicates that qualitative analyses are appropriate because they prioritize the evaluation of micro processes, allowing for an intensive evaluation both in amplitude and depth of the data obtained. Yin (2005) complements that scientific studies aimed at answering questions such as "how" and "why", are considered exploratory research, being more appropriate to use case studies. 
In this context, a qualitative exploratory research was carried out, through a study of multiple cases that investigated projects in different companies and in different branches of activity, such as industrial, commercial and service provision projects.

In order to obtain the data for the study of multiple cases, the research was conducted through an interview guided by a semi-structured orientation script, adapted from the script proposed by Gusberti et al. (2009). The script was divided into three sections, the first one to obtain the general information about the company where the interview was conducted and its projects held (8 open questions), the second to evaluate the indirect cost identification mechanisms (5 open questions) and to evaluate the methods used to estimate and to appropriate indirect costs in the company's projects ( 7 open and two closed questions). The script has mostly open-ended questions and two closed-ended questions, one of which used the Likert scale (Likert, 1932) with 7 response alternatives ranging from 1 (very easy) to 7 (too complex) for the respondent to indicate the level of difficulty (effort) in estimating the indirect costs of the project.

According to Triviños (1987), the semi-structured interviews are those that start from basic questions, based on the bibliographic survey related to the objective of the study and on the possible hypotheses that may complement the research. This model allows formulating new hypotheses that will arise during the interview and as the answers are provided by the respondent.

As criteria for selecting the participating companies, the following intentional criteria were considered: the time of company maturity in doing projects, i.e. at least five years of maturity, considering that the participating companies should have a maturity period in project management (Prado, 2010). It was also intentional to study organizations that developed projects in different branches of activity to reduce the bias of the influence of a given branch on the way indirect project management is carried out, and thus increase the possibility of generalizing the research results. We selected companies with projects in the industrial, commercial and service provision sectors.

For collecting information, interviews were conducted with those responsible for project cost management, such as coordinators, managers or directors in their respective organizations. The selection of the interviewees was also intentional and was carried out with the purpose of interviewing professionals with knowledge in the area of project costing or cost management in projects, and who had acted for at least two years in the organization as coordinators, managers or directors, considering it a reasonable time for the professionals to be familiar with the cost management processes in projects in the company.

After obtaining the data, comparisons of the data obtained between the cases and with the theoretical framework were performed.

\section{Presentation and discussion of results}

\subsection{Company A}

Company A, with projects in the Industrial branch, has more than 50 years of existence and has more than 100 employees. It produces plastic products for use in various activities, both residential and industrial. Simple products, such as plastic cups, but also more complex products, such as plastic equipment for automotive vehicles (parts in general) are developed. 
The projects carried out by this company are basically aimed at developing new products, covering the entire structuring of a product idea, design elaboration, mold making and machinery, physical and chemical tests, production tests and pilot production.

The interview was held with the founding partner, who holds the position of chief financial officer, and has a degree in engineering. He has more than 20 years of experience in financial and cost evaluation. The interview lasted about 1 hour and 10 minutes and was held face-to-face.

In Company A, indirect costs are identified in all projects. According to the interviewee, "these costs are mainly raised after the stage of structuring the idea, outlining the scope, defining the deadline requested by the client and analyzing the period required for product development and, consequently, the project closure." Therefore, indirect costs are identified in the project planning stage, that is, in the budget preparation.

The interviewee attributes an intermediate difficulty in identifying indirect costs (rating 3), on a scale ranging from 1 (very easy) to 7 (very complex). For the interviewee, "the difficulty in identifying the costs is not considered very complex", because the company has a close control of the history of the costs of previous projects and most of the times, they are used to helping to determine the budget of new projects. The interviewee pointed out that "the projects developed have great similarity, facilitating the use of previous project histories for measuring direct and indirect costs". This company stores the cost history of the projects in a digital medium, especially in worksheets that are continuously revised and used as references for future budgets and for evaluating the indicators of each project.

The costs identified in the planning stage of each project are controlled and, whenever there is any kind of change, revisions are made in the planning of activities and costs are updated. After the project's completion, the results are evaluated, and kept archived for future projects. The company estimates the costs based on planned and standardized methods for all projects.

As explained by the interviewee, "there are no cases of project failure due to lack of identification of indirect costs". Past cases of project failure were mentioned to have occurred due to failures in identifying and measuring indirect costs. However, after gaining experience in the segment and using similar project histories, there was a significant reduction in project failure due to failures in identifying costs.

As reported by the interviewee, the strategy adopted in the appropriation of costs by this company is the representation of each machine as if it were a single company, each equipment has its input and its financial output and consumes some direct and indirect resources. All indirect costs, even from the administrative or structural area of the company, are appropriated in the direct costs of the machine hour, making it possible to very precisely evaluate the costs related to the operation of the plant and the development of each new product project.

According to the interviewee, "[...] there are more accurate calculation methods for estimation and appropriation of indirect costs; however, the effort and costs for these methods are very high when compared to the representation of indirect costs for the development of a given project." The interviewee pointed out that in the cases of the projects developed by this company, indirect costs are very close to the direct costs, and there is no need for further analysis of these costs. 


\subsection{Company B}

Company B develops projects in the commercial segment, and operates in the Brazilian food sector. With over 20 years of existence, has around 200 employees and produces more than 1.2 thousand liters of ice cream per day. Its main customers are the resellers (franchises).

The company's projects are focused on promotional campaigns (projects in the commercial area), presenting as main objectives: grow sales, improve the turnover of factories and franchise stocks, brand positioning and marketing.

These projects have an evaluation of the sale scenario in the medium term, mainly considering the seasonality (winter and summer) and the ice cream flavors targeted by the campaign. These campaigns are programmed, according to the ice cream volume to be sold or one pre-established period. The projects main activities are: study of the market, strategic evaluation, marketing development, communication plan, studies of sales price, production, distribution and control until the deadline is accomplished or the volume determined for the campaign.

The interview in this company was carried out with the shareholder, who is the executive director in one of the company's factories, has a degree in economics, and over 15 years of experience in the financial area. This interview was conducted in person and lasted about 40 minutes.

In this company, indirect costs are identified in all projects. The costs are estimated after the scope design and the calculation of the project duration activities, in the stage of project planning. Since the projects are promotional campaigns, they are developed internally by the company and the deadline is established according to a pre-determined period or products sales volume.

The interviewee attributes a minimal difficulty in identifying indirect costs (rating 1), on a scale ranging from 1 (very easy) to 7 (very complex). The interviewee mentioned that "[...] the projects developed are quite controlled and are carried out with a certain regularity, as well as involving few activities; the indirect costs are well known by the company".

Whenever new projects are structured, the costs (direct and indirect) are identified with the representatives of each area, who adopt the brainstorming method to discuss the resources required for each project activity. In all projects, the WBS is developed and the cost baseline is structured. In fact, planning meetings are held with members of all the departments involved, to jointly identify the costs and help to build the budget of each campaign.

In addition to evaluating the projects in meetings with specialists, the company also has the history of previous projects that are archived in digital medium and used whenever similar projects are developed, helping to identify the project costs.

The project costs are constantly evaluated by the company and updated whenever there are changes in the scope or in the deadline. There are continuous planning reviews so that they can reflect the projects reality. This process is archived at the end of each project and becomes a reference for similar projects.

According to the interviewee, "[...] the main indirect project costs considered by this company are basically the costs of the administrative area (personnel, financial and legal department), as well as the costs of the structure (electricity, telephony, water, internet, and leasing of printers)“.

As reported by the interviewee, there were no cases of project failure due to failing to identify or to measure indirect costs, since they are not very representative in their total project costs, but there have already been projects in which direct costs were 
incorrectly estimated, frustrating the desired success. In such cases, regardless of whether the erroneous estimates are in cost, time, or scope, they are reported at project completion and are maintained so that these deviations can be corrected in future projects.

As pointed out by the interviewee, "[...] in the first projects of promotional campaigns, indirect costs were estimated without any kind of premise, yet they have always been controlled and evaluated, constituting a robust database that is used for future budgets."

It was found that no specific software is used for identifying and estimating indirect costs; they are calculated through basic spreadsheet development systems. In addition, according to the interviewee, "[...] indirect costs are estimated by evaluating each type of resource used, aiming mainly at fragmenting indirect and direct costs, for each quantity of product sold by the project."

The interviewee emphasized that the process adopted for the appropriation of indirect costs is feasible because the quantity of product is a determinant for the closure of the project; therefore, all the calculations are made based on the maximum of products sold during the promotional campaign.

Indirect costs that are not directly related to products, such as costs of the administrative area and the structure of the company, are also fragmented into smaller portions and appropriated to the cost of production of the project target product.

As stated by the interviewee,

[...] indirect costs do not have a great influence on the total cost of the project because the representativeness of these costs is significantly lower compared to the direct costs of the project; for example, communication and marketing costs, which represent the greater part of the project costs.

The interviewee said that the projects are constantly monitored and controlled until their conclusion, and after the conclusion, meetings of lessons learned take place, and the project success is evaluated; the positive and negative points are raised and serve as reference for future projects.

\subsection{Company C}

From the service sector, Company $C$ has over 15 years of experience and has over 80 employees. This company sells services in the area of environmental management and environmental engineering. The main clients of this company are projects under construction or in operation, which require assistance in the area of environmental licensing.

The projects developed by this company basically have five stages: survey of the legislation, diagnosis, elaboration, protocol and monitoring of the public organizations. Their projects are developed to enable their clients to perform a work or to maintain their operation within the applicable laws.

In this company, the minority shareholder was interviewed, who holds the position of commercial director. He has degree in advertising and biology, with more than 10 years of experience in the financial and commercial area. This interview was conducted in person and lasted about 50 minutes.

The interviewee reported that indirect costs are identified for almost all the company projects. The main step to collect these costs is after the project briefing meeting, that 
is, in the planning stage, because "[...] it is from this meeting that the client's needs, the expectations and the products that are to be delivered are raised. After this stage, the necessary activities evaluations are carried out and then the project costs are identified and measured".

However, as informed by the interviewee, "Not all projects consider indirect costs in their budgets; only direct costs, profit margin and taxes are evaluated." According to the interviewee, "[...] when considering indirect costs in the project, the value of the technical hour is very high, making the project economically unfeasible."

In this sense, the interviewee complemented that the indirect costs of projects that have low profit margin are supplied by projects that have a higher profit margin.

According to the interviewee, the difficulty of identifying the indirect costs of projects received rating 5 , ranging from 1 (very easy) to 7 (very complex), which indicates a high difficulty in the evaluation of indirect costs. According to the interviewee, this is because their projects have little duration and little similarity between their activities.

The interviewee stated that, "[...] the difficulty is amplified, especially when the scope has not been correctly defined by the client, causing the unexpected consumption of resources, no matter if direct or indirect." It was also mentioned that "[...] the company has a history of previous projects, but they are not formally stored". In fact, this depends on the experience of who is conducting a new project, if the experience with cost estimates from previous projects will be used or not.

As mentioned by the interviewee, the company does not have a formalized methodology for identifying and measuring indirect costs; they are actually considered subjectively and only in some cases are included in the budgets of the projects.

The interviewee highlighted that "[...] there are no cases of project failure due to indirect costs, but it cannot be said that the company is being efficient in managing the indirect costs in its projects, since there have already been cases in which the planned project profit was not obtained".

As reported by the interviewee, "there are cases in which direct and indirect costs are not completely predictable and sometimes events occur that were not initially planned for executing the project." In these cases, the experience gained is shared with those involved in the process and gathered in the form of experience (not formalized), so that they are considered in future projects.

\subsection{Results discussion}

The discussion of the results was divided into three subsections that correspond to the processes related to the management of indirect costs in projects. The research objective was to investigate the identification, estimation and appropriation of indirect costs.

\subsubsection{Indirect costs identification}

As observed in the results presented, the three companies analyzed identify the indirect costs in the project planning stage, mainly at the moment the project objectives and the definition of the scope are determined, that is, in the budget stage. These results corroborate the bibliography presented, in which several authors point out that it is fundamental to identify costs in the planning stage because, at this moment, the 
project is structuring the scope and deadline, and these are the main factors that directly influence the project budget (Shenhar et al., 2002; Santos \& Martins, 2008).

Likewise, the results showed that Company A starts the process of identifying indirect costs when the requirements (scope) of the project are defined by the client; Company B makes its cost evaluations at favorable moments (based on seasonality) for developing its projects; and Company $\mathrm{C}$ carries out analyses for elaborating commercial proposals, when demanded by its clients. These data converge with the information published by Barbosa et al. (2014), which mentions that each organization determines the start of evaluations of its projects, and that it is more advisable for costs to be identified in phases in which reprogramming has not affected the outcome of the project, i.e., in the planning stages.

Regarding the degree of difficulty in identifying indirect costs by the analyzed companies, by making a comparative analysis between the declared difficulty in identifying the project costs and the use the WBS of the projects, this study showed that the companies that adopt the WBS have an easier time to determine the direct and indirect costs. Rad (2002) points out that the use of the WBS is fundamental for identifying all the necessary resources for a project. Carvalho \& Rabechini (2011) complement that the WBS helps to quantify the consumption of each resource in a project and not using it can hinder the identification of all the necessary costs for its execution.

Regarding the lack of historical data mentioned by the interviewee of company C, it can be said that this factor can contribute to the difficulty in identifying the indirect costs reported by him, since the information from previous projects serves as reference for future projects, as mentioned by Rad (2002) and by Carvalho \& Rabechini (2011). In this context, Rad (2002) describes in his study that the availability of previous historical project data is an important tool for identifying and developing estimation models, since it provides parameters of projects already performed by the company, which can be used for a reliable evaluation of the estimated data.

The three companies were observed to consider the administrative costs and the costs expended with the company structure as indirect costs of the developed projects. However, the interviewee of Company A highlighted that in addition to separating the costs into direct (those that occur directly for conducting the project) and indirect (those supporting the project), costs are also considered semi-indirect by them. According to the interviewee, these costs are those generated as a result of a series of direct costs, such as team supervision, management and accessory machines. This example can be explained by Martins (2003), who points out that all indirect costs have a certain subjectivity, to a smaller or larger degree, when they are identified, estimated and appropriated.

In this context, the fragmentation of indirect costs into "semi-indirect", as mentioned by Company $A$, seems to be nothing more than a subclassification of indirect costs between those who have a higher or a lower degree of subjectivity, and there is no divergence with the theoretical definitions presented in the literature.

\subsubsection{Indirect costs estimate}

Evaluating the information provided in the interviews, the three companies use historical information to estimate the indirect costs of future projects. However, only companies $A$ and $B$ present more precise methods and with a lower degree of subjectivity, Company $\mathrm{C}$ performs its statistical calculations with a lower level of detail. 
According to Rad (2002), estimates made from experience are more direct forms, usually do not use detailed data and are solely based on experience, skill, knowledge, intuition and empirical historical data. Carvalho \& Rabechini (2011) complement that the level of detail depends on the time available for calculations and the degree of information available.

However, as previously reported, Company $\mathrm{C}$ does not have archived historical data, it only uses experts' experiences to develop the project indirect costs calculations. Rad (2002) points out that these data can also be considered a reliable source of project estimation, assisting mainly in situations of lack of historical data of similar projects.

\subsubsection{Appropriation of indirect costs}

Regarding the appropriation of indirect costs in the budget of a project the three companies studied were observed to present specific methods for these costs to be considered for each project developed.

According to the results from the Company $A$, we observed that the main intention of this company is to appropriate the projects indirect costs of the projects in the hours spent on each of their machines. As all the projects of this company result in a certain number of products produced, the indirect costs are appropriated in the machine hours and calculated according to the production. Martins (2003) named this method of appropriation Costing of the Production Effort Unit. This method uses a way of measuring the efforts of each resource applied to manufacturing one or several products, as described in the study by Bornia (1995).

In turn, in the interview conducted in Company B, the appropriation of indirect costs was observed to be carried out based on the fragmentation of the project by activities, using the WBS method. The information provided by the interviewee corroborates the study by Abbas et al. (2012), since these authors mention that this method assumes that the resources are consumed by the activities that make up a product.

Martins (2003) complements that this method of appropriation of the indirect costs is the one that presents smaller distortions, being the method of more rational apportionment of the indirect costs. However, for better use, the costs must be distributed across the tasks and later across the production activities, mainly using the WBS method for greater precision of the project activities.

Finally, in the interview with Company $\mathrm{C}$, two models of appropriation of project costs were observed, being evaluated case by case. The first model presented by company C is considered by Martins (2003) the absorption method, which is the simplest, since all the production costs will compose the cost of the good or service; these are apportioned to all the products of a project. Another relevant factor that corroborates the study by Martins (2003) is the division of indirect costs into production departments and auxiliary departments, this technique being characteristic of the absorption method.

However, in the other model presented by company $\mathrm{C}$, in which the indirect costs (the organization fixed costs) are neglected, considering only the variable and direct costs to the project, are characteristic of the variable costing method, this type of costing being the focus of the study conducted by Martins (2003) and Zahaikevitch et al. (2013). 
Table 3 provides a summary of all the results presented in this study, allowing to better understand the information obtained in the interviews and discussed in this chapter.

Table 3. Summary of results.

\begin{tabular}{|c|c|c|c|c|c|c|c|c|}
\hline Case & $\begin{array}{c}\text { Activit } \\
\text { y } \\
\text { Branch }\end{array}$ & $\begin{array}{c}\text { Sales } \\
\text { Represent } \\
\text { ations }\end{array}$ & $\begin{array}{l}\text { Level of } \\
\text { Difficulty in } \\
\text { Identifying } \\
\text { Indirect } \\
\text { Costs }^{1}\end{array}$ & $\begin{array}{c}\text { WBS } \\
\text { Developm } \\
\text { ent }\end{array}$ & $\begin{array}{l}\text { History of } \\
\text { Indirect } \\
\text { Cost } \\
\text { Identificati } \\
\text { on }\end{array}$ & $\begin{array}{l}\text { Identificat } \\
\text { ion of } \\
\text { Indirect } \\
\text { Costs } \\
\text { Criteria }\end{array}$ & $\begin{array}{l}\text { Method } \\
\quad \text { for } \\
\text { Estimatin } \\
\text { g Indirect } \\
\text { Costs }\end{array}$ & $\begin{array}{c}\text { Method for } \\
\text { Appropriat } \\
\text { ing } \\
\text { Indirect } \\
\text { Costs }\end{array}$ \\
\hline $\begin{array}{c}\text { Company } \\
\text { A }\end{array}$ & $\begin{array}{c}\text { Industr } \\
\mathrm{y}\end{array}$ & $\begin{array}{c}40 \% \text { of } \\
\text { new } \\
\text { product } \\
\text { projects } \\
60 \% \text { mass } \\
\text { production }\end{array}$ & $\begin{array}{c}3 \\
\text { (Intermediate } \\
\text { Difficulty). } \\
\text { Regarding } \\
\text { the large } \\
\text { quantity of } \\
\text { costs } \\
\text { involved in } \\
\text { their projects. }\end{array}$ & $\begin{array}{l}\text { No, but the } \\
\text { projects } \\
\text { have a } \\
\text { close } \\
\text { control of } \\
\text { the costs } \\
\text { and of their } \\
\text { progress, } \\
\text { for history } \\
\text { archiving }\end{array}$ & $\begin{array}{c}\text { Project } \\
\text { documents } \\
\text { are } \\
\text { archived } \\
\text { electronica } \\
\text { lly and are } \\
\text { used for } \\
\text { identifying } \\
\text { and } \\
\text { estimating } \\
\text { indirect } \\
\text { costs. }\end{array}$ & $\begin{array}{l}\text { They } \\
\text { identify the } \\
\text { indirect } \\
\text { costs for } \\
\text { all the } \\
\text { projects } \\
\text { developed, } \\
\text { based on } \\
\text { the } \\
\text { historical } \\
\text { data. }\end{array}$ & $\begin{array}{l}\text { Parametric } \\
\text { and } \\
\text { Modular } \\
\text { Estimation. } \\
\text { Based on } \\
\text { mathemati } \\
\text { cal } \\
\text { models, } \\
\text { past } \\
\text { experience } \\
\text { and project } \\
\text { archives. }\end{array}$ & $\begin{array}{c}\text { Production } \\
\text { Effort Unit } \\
\text { Method. All } \\
\text { the } \\
\text { overhead } \\
\text { (indirect) } \\
\text { costs are } \\
\text { appropriate } \\
\text { d at the } \\
\text { time of } \\
\text { machine } \\
\text { operation. }\end{array}$ \\
\hline $\begin{array}{c}\text { Company } \\
\text { B }\end{array}$ & $\begin{array}{c}\text { Comme } \\
\text { rce }\end{array}$ & $\begin{array}{l}20 \% \text { of the } \\
\text { projects } \\
\text { for } \\
\text { promotion } \\
\text { al } \\
\text { campaigns } \\
\text { and } 80 \% \\
\text { for mass } \\
\text { production. }\end{array}$ & $\begin{array}{c}1 \text { (Low } \\
\text { Difficulty). } \\
\text { Attributed } \\
\text { because the } \\
\text { projects } \\
\text { present great } \\
\text { similarity } \\
\text { among } \\
\text { themselves, } \\
\text { being able to } \\
\text { be replicated } \\
\text { and adjusted } \\
\text { for the other } \\
\text { projects. }\end{array}$ & $\begin{array}{c}\text { Yes, in } \\
\text { addition to } \\
\text { other tools } \\
\text { suggested } \\
\text { by the } \\
\text { project } \\
\text { manageme } \\
\text { nt manuals } \\
\text { (schedule, } \\
\text { cost } \\
\text { control, } \\
\text { among } \\
\text { others). }\end{array}$ & $\begin{array}{l}\text { Company } \\
\text { B archives } \\
\text { the history } \\
\text { of previous } \\
\text { projects, } \\
\text { which are } \\
\text { used to } \\
\text { identify } \\
\text { and to } \\
\text { assist in } \\
\text { the } \\
\text { statistics } \\
\text { for } \\
\text { measuring } \\
\text { indirect } \\
\text { costs. }\end{array}$ & $\begin{array}{c}\text { They } \\
\text { identify the } \\
\text { indirect } \\
\text { costs for } \\
\text { all projects } \\
\text { using the } \\
\text { WBS tool } \\
\text { as a way } \\
\text { of detailing } \\
\text { the } \\
\text { activities. }\end{array}$ & $\begin{array}{l}\text { Bottom-up } \\
\text { Estimate. } \\
\text { Use of } \\
\text { WBS, } \\
\text { Brainstorm } \\
\text { ing with } \\
\text { experts } \\
\text { and past } \\
\text { project } \\
\text { history. }\end{array}$ & $\begin{array}{l}\text { Activity- } \\
\text { Based } \\
\text { Costing } \\
\text { Method. } \\
\text { Indirect } \\
\text { costs are } \\
\text { assigned to } \\
\text { each } \\
\text { activity and } \\
\text { diluted for } \\
\text { each } \\
\text { project } \\
\text { product. }\end{array}$ \\
\hline $\begin{array}{c}\text { Company } \\
\text { C }\end{array}$ & $\begin{array}{l}\text { Service } \\
\text { Provision }\end{array}$ & $\begin{array}{l}100 \% \text { of } \\
\text { projects }\end{array}$ & $\begin{array}{c}5 \text { (High } \\
\text { difficulty). } \\
\text { Linked } \\
\text { mainly to the } \\
\text { low similarity } \\
\text { between the } \\
\text { projects and } \\
\text { short } \\
\text { deadlines for } \\
\text { planning their } \\
\text { projects } \\
\text { (from } 1 \text { to } 2 \\
\text { days). }\end{array}$ & $\begin{array}{c}\text { No, } \\
\text { because } \\
\text { the short } \\
\text { period for } \\
\text { sending } \\
\text { their } \\
\text { budgets to } \\
\text { clients, } \\
\text { makes it } \\
\text { difficult to } \\
\text { develop } \\
\text { the WBS. }\end{array}$ & $\begin{array}{l}\text { The } \\
\text { histories of } \\
\text { the } \\
\text { previous } \\
\text { projects } \\
\text { are not } \\
\text { archived } \\
\text { by formal } \\
\text { means, } \\
\text { and are } \\
\text { stored in } \\
\text { form of } \\
\text { learning } \\
\text { (Know } \\
\text { how) of the } \\
\text { managers. }\end{array}$ & $\begin{array}{l}\text { Indirect } \\
\text { costs are } \\
\text { not } \\
\text { identified } \\
\text { for all } \\
\text { projects. } \\
\text { More } \\
\text { profitable } \\
\text { projects } \\
\text { outweigh } \\
\text { the less } \\
\text { profitable } \\
\text { ones. }\end{array}$ & $\begin{array}{l}\text { Estimate } \\
\text { by } \\
\text { Experienc } \\
\text { e. } \\
\text { It is } \\
\text { applied } \\
\text { according } \\
\text { to the } \\
\text { experience } \\
\text { of the } \\
\text { person in } \\
\text { charge of } \\
\text { planning } \\
\text { (Heuristics). }\end{array}$ & $\begin{array}{l}\text { Absorption } \\
\text { Costing } \\
\text { Method and } \\
\text { Variable } \\
\text { Costing } \\
\text { Method. } \\
\text { Costing of } \\
\text { indirect } \\
\text { costs in the } \\
\text { direct } \\
\text { technical } \\
\text { hours or } \\
\text { are } \\
\text { considered } \\
\text { only the } \\
\text { direct costs } \\
\text { of the } \\
\text { projects. }\end{array}$ \\
\hline
\end{tabular}

\section{Conclusion}

This research reached the proposed objectives by promoting a more detailed discussion of methods for identifying indirect costs in projects, as well as evaluating the estimation models adopted by companies to quantify these costs, besides analyzing the ways of appropriating indirect costs in projects in different situations.

The study of multiple cases was adequate because it enabled the evaluation of micro processes and, therefore, a broader and deeper investigation in companies and 
in their projects. The interviews enabled the collection of information that allowed a comparison between the results for projects in different branches of activity.

The information collected from companies with projects in the industrial, commercial and service sectors showed that the difficulty in identifying indirect costs is independent of the branch of activity whereby the project was developed. Conversely, it was possible to perceive that the projects managed with methods for better detailing the project scope from the planning phase present less difficulty in identifying indirect costs. In this sense, the time available for planning the project can be decisive for a complete survey of the indirect costs, since it presupposes the greater detail of the scope.

Regarding the analysis of the methods for estimating indirect costs in projects, the use of different methods stands out, such as, the bottom up method (with the help of the WBS tool), the parametric and modular estimation method (using mathematical calculations and historical data) and the experience-based method (using the know-how of managers). The appropriation of indirect costs presented variation for projects of different branches of activity, but show a common objective, that is, to be achieved through the fragmentation of costs and based on the estimates adopted by the companies, to compose the direct cost of their projects.

This study contributes to the analysis of the methods of identification, measurement and appropriation of indirect costs in the budget and planning phases of the projects. It serves as an aid to all those involved in these project phases, allowing a better understanding of cost management. The study extends the knowledge of the existing literature on the influence of the planning stage to the identification and measurement of indirect costs in projects in different branches of activity.

This multiple case study has limitations because it is not able to generate the same results as the controlled experiments (e.g. surveys) in terms of causal relationships, but it provided a deeper understanding of the phenomena studied. However, the results cannot be generalized, and are valid only for the analyzed context. As a suggestion for future work, we propose extending the study of indirect costs in projects to other sectors not covered in this study, such as civil construction and information technology, as well as to evaluate which methods are most satisfactory for developing the project budget.

\section{References}

Abbas, K., Gonçalves, M. N., \& Leoncine, M. (2012). Os métodos de custeio: vantagens, desvantagens e sua aplicabilidade nos diversos tipos de organizações apresentadas pela literatura. ConTexto, 12(22), 145-159.

Atkinson, R. (1999). Project management: cost, time and quality, two best guesses and a phenomenon, its time to accept other success criteria. International Journal of Project Management, 17(6), 337-342. http://dx.doi.org/10.1016/S0263-7863(98)00069-6.

Barbosa, C., Nascimento, C. A. D., Abdollahyan, F., \& Pontes, R. M. (2014). Gerenciamento de custos em projetos. Rio de Janeiro: Editora FGV.

Barcellos, M. P., Figueiredo, S. M., Rocha, A. R., \& Travassos, G. (2003). Utilização de métodos paramétricos, analogias, julgamento de especialistas e conhecimento original no planejamento de tempo, custo de projetos de software. In Anais do II Simpósio Brasileiro de Qualidade de Software (pp. 1-15). São Paulo: SBC.

Berssaneti, F. T., \& Carvalho, M. M. (2015). Identification of variables that impact project success in Brazilian companies. International Journal of Project Management, 33(3), 638-649. http://dx.doi.org/10.1016/j.ijproman.2014.07.002. 
Bornia, A. C. A. (1995). A fusão de postos operativos no método da unidade de esforços de produção. In Anais do IV Congresso Internacional de Custos e II Congresso Brasileiro de Gestão Estratégica de Custos (pp. 481-491). Campinas: UNICAMP.

Carvalho, M. M., \& Rabechini, R. J. (2011). Fundamentos em gestão de projetos: construindo uma competência para gerenciar projetos. São Paulo: Editora Atlas.

Costa, A. P. C. S., Silva, L. C., \& Bastos, R. N. (2009). Modelo de decisão para alocação de recursos humanos em projetos de sistemas de inovação. In Anais do XXIX Encontro Nacional de Engenharia de Produção (pp. 1-14). Salvador: ABEPRO.

Gusberti, T. D. H., Hilgert, R. N., \& Echeveste, M. E. S. (2009). Análise gerencial de custos em empresa de prestação de serviços de base tecnológica de médio porte. In: Anais XXIX Encontro Nacional de Engenharia de Produção (pp. 1-13). Salvador: ABEPRO.

Kerzner, H. (2011). Gerenciamento de projetos: uma abordagem sistêmica para planejamento, programação e controle. São Paulo: Editora Blucher.

Knutson, J., \& Bitz, I. (1991). Project management: how to plan and manage successful projects. New York: Amacom.

Kreisch, L. (2013). Projeto, orçamentação e planejamento de obra de pequeno porte (Trabalho de Conclusão de Curso de Graduação). Universidade do Planalto Catarinense, Lages.

Lacerda, R. T. O. (2009). O sucesso em gerenciamento de projetos: a estruturação de um modelo de avaliação a partir de uma visão construtivista (Dissertação de mestrado). Universidade Federal de Santa Catarina, Florianópolis.

Lewis, J. P. (1995). Fundamentals of project management. Nova York: Amacom Books.

Likert, R. (1932). A technique for the measurement of attitudes. Archives de Psychologie, 140, $1-55$.

Lipovetsky, S., Tishler, A., Dvir, D., \& Shenhar, A. (1997). The relative importance of project success dimensions. $R \& D$ Management, 27(2), 97-106. http://dx.doi.org/10.1111/14679310.00047.

Martins, E. (2003). Contabilidade de custos (9. ed.). São Paulo: Atlas.

Martins, H. H. T. S. (2004). Metodologia qualitativa de pesquisa. Educação e Pesquisa, 30(2), 289-300. http://dx.doi.org/10.1590/S1517-97022004000200007.

Meredith, J. R., \& Mantel, S. J. J. (2012). Project management: a managerial approach. Jefferson City: John Wiley \& Sons.

Obi, L. I., Arif, M., \& Kulonda, D. J. (2017). Prioritizing cost management system considerations for Nigerian housing projects. Journal of Financial Management of Property and Construction, 22(2), 135-153. http://dx.doi.org/10.1108/JFMPC-06-2016-0025.

Oliveira, R. C. F. (2003). Gerenciamento de projeto e a aplicação da análise de valor agregado em grandes projetos (Dissertação de mestrado). Escola Politécnica, Universidade de São Paulo, São Paulo.

Pinto, A. A. G., Limeira, A. L. F., Silva, C. A. S., \& Coelho, F. S. (2008). Gestão de custos. Rio de Janeiro: Editora FGV.

Prado, D. (2010). Fundamentos do Modelo Prado - MMGP. Retrieved in 2018, June 11, from www.maturityresearch.com

Project Management Institute - PMI. (2017). Um guia do conhecimento em gerenciamento de projetos (guia PMBOK) (6. ed.). Pennsylvania: Project Management Institute, Inc.

Rad, P. F. (2002). Project estimating and cost management. Vienna: Editora Management Concept.

Rodrigues, I., Júnior, R. R., \& Csillag, J. M. (2006). Os escritórios de projetos como indutores de maturidade em gestão de projetos. Revista $A D M, 41(3), 273-287$.

Santos, J. A. (2015). Gestão de Projetos. Curitiba: Universidade Positivo. 
Santos, L. G. C., \& Martins, M. R. (2008). Análise da influência da evolução na maturidade em gerenciamento no desempenho dos projetos. In Anais do XV SIMPEP - Simpósio de Engenharia de Produção (pp. 1-12). Bauru: UNESP.

Schier, C. U. C. (2006). Gestão de custos. Curitiba: Ibpex.

Shenhar, A. J., Raz, T., \& Dvir, D. (2002). Risk management, project success, and technological uncertainty. $R \&$ \& Management, 32(2), 101-109. http://dx.doi.org/10.1111/14679310.00243.

Triviños, A. N. S. (1987). Introdução à pesquisa em ciências sociais: a pesquisa qualitativa em educação. São Paulo: Editora Atlas.

Tukel, O. I., \& Rom, W. O. (2001). An empirical investigation of project evaluation criteria. International Journal of Operations \& Production Management, 21(3), 400-416. http://dx.doi.org/10.1108/01443570110364704.

Vargas, V. R. (2005). Gerenciamento de projetos: estabelecendo diferenciais competitivos. Rio de Janeiro: Brasport.

Werolin, A. E. (1965). A elaboração de um orçamento variável. Revista de Administração de Empresas, 5(16), 127-144. http://dx.doi.org/10.1590/S0034-75901965000300006.

Yin, R. K. (2005). Estudo de caso: planejamento e métodos (2. ed.). Porto Alegre: Bookman.

Zahaikevitch, E. V., Matos, S. N., \& Gapinski, E. F. P. (2013). Métodos de custeio utilizados na precificação: um estudo de caso. In Anais do XXXIII Encontro Nacional de Engenharia de Produção (pp. 1-15). Rio de Janeiro: ABEPRO. 